Historic, archived document

Do not assume content reflects current scientific knowledge, policies, or practices. 

Ag'84m Department of Agriculture

Animal and

Plant Health

Inspection

Service

Miscellaneous

Publication No. 1537

\section{Animal Damage Control Program Highlights, 1995}

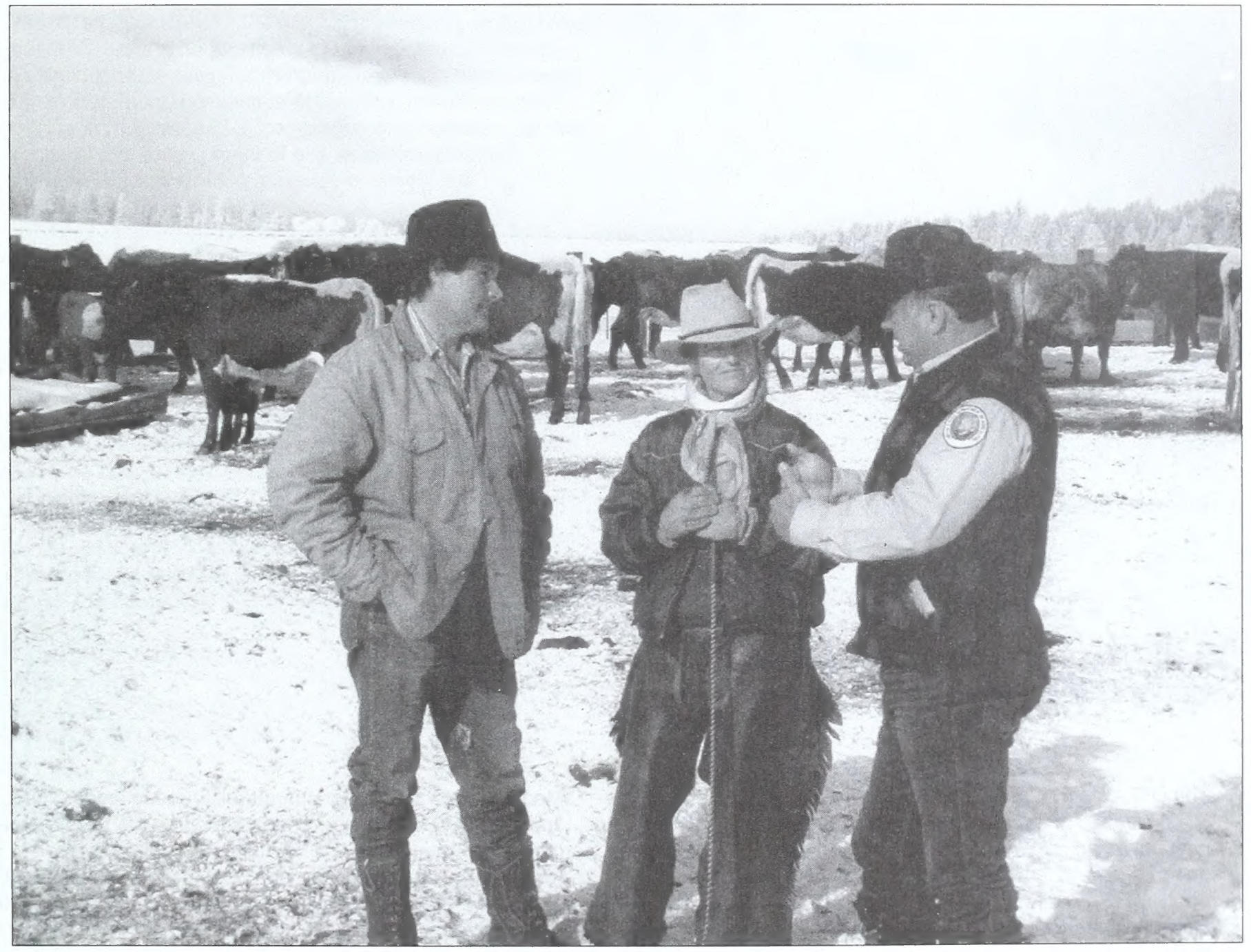


Cover photo by Stan Thomas, APHIS. Interior photos are from the APHIS library.

The U.S. Department of Agriculture (USDA) prohibits discrimination in its programs on the basis of race, color, national origin, sex, religion, age, disability, political beliefs, and marital and familial status. (Not all prohibited bases apply to all programs.) Persons with disabilities who require alternative means for communication of program information (braille, large print, audiotape, etc.) should contact the USDA Office of Communications at (202) 720-2791.

To file a complaint, write the Secretary of Agriculture, U.S. Department of Agriculture, Washington, DC 20250, or call (202) 720-7327 (voice) or (202) 720-1127 (TDD). USDA is an equal opportunity employer.
Mention of companies or commercial products does not imply recommendation or endorsement by the USDA over others not mentioned. USDA neither guarantees nor warrants the standard of any product mentioned. Product names are mentioned solely to report factually on available data and to provide specific information.

This publication reports activity involving pesticides. All uses of pesticides must be registered by appropriate State and/or Federal agencies before they can be recommended.

CAUTION: Pesticides can be injurious to humans, domestic animals, desirable plants, and fish or other wildlife-if they are not handled or applied properly. Use all pesticides selectively and carefully. Follow recommended practices for the disposal of surplus pesticides and pesticide containers. 
Since 1985, the Federal Government's efforts to manage wildlife damage to agricultural and other resources have been centralized in the U.S. Department of Agriculture's (USDA) Animal and Plant Health Inspection Service (APHIS). APHIS' Animal Damage Control (ADC) program works to minimize the effects of wildlife on livestock and crops and to protect human health and safety from wildlife damage as well.

This report documents ADC's accomplishments during fiscal year (FY) 1995. The highlights of the year include signing the Record of Decision for the programmatic environmental impact statement, completion of the new animal research building in Ft. Collins, CO, completion of a customer service brochure, the development of two workforce planning initiatives, and continuing research on innovative approaches to lessen wildlife damage. In addition to traditional responsibilities for protecting agricultural resources, we continued our involvement in the protection of human health and safety and threatened and endangered species.

Preparing the 1995 highlights report is one way we are working to keep the public and our State and local cooperators better informed about ADC activities. To learn more about our research activities, you are encouraged to request a copy of the Denver Wildlife Research Center Highlights Report, Fiscal Year 1995. Write to USDA/APHIS/ DWRC, Building 16, P.O. Box 25266, Denver Federal

Center, Denver, CO 80225-0266, and ask for Miscellaneous Publication 1533. For more details about the overall ADC program, please write to:

Deputy Administrator, ADC

USDA, APHIS

4700 River Road, Unit 87

Riverdale, MD 20737-1234 


\section{New Strategic Plan}

In October 1994, ADC published Animal Damage Control: Mission and Strategy-a new strategic plan-which was the result of a long process involving a "futuring" exercise that began in 1991 and involved employees at all levels within the program. We recognized the need for increased public awareness of the extent and magnitude of wildlife damage problems, as well as the need for socially acceptable and effective control methods. The new strategic plan has been provided to ADC employees and stakeholders. You may request a copy by writing to $A D C$ at the Riverdale, MD, address given on page 3 .

\section{Sheep and Goat Loss Survey}

ADC has continued its interagency agreement with USDA's National Agricultural Statistics Service (NASS) to determine the magnitude and extent of wildlife damage to various agricultural resources. In May 1995, NASS released the results of its survey to determine predator losses to the sheep and goat industry. Results indicated that, during 1994, predators killed 368,050 sheep and lambs valued at $\$ 17.7$ million. Predators also killed 140,000 goats valued at $\$ 5.5$ million. Coyotes continued to be the largest single predator of sheep and goats, followed by feral dogs.

NASS also documented in the survey that both fencing and husbandry practices tied for the leading nonlethal control measures used during 1994, and farmers and ranchers spent an average of $\$ 1.77$ per breeding animal on nonlethal control compared to $\$ 0.50$ for lethal measures. The ADC program has renewed the NASS contract to obtain information regarding the amount of agricultural losses caused by wildlife on an annual basis.

\section{Program Development Activities}

The total cooperative funding provided to the ADC program increased by approximately $\$ 2$ million during 1995 . The majority of this funding was allocated for beaver control and human health and safety projects. Examples follow.

In Nebraska, the governor signed a bill providing $\$ 50,000$ per year for animal damage control activities in that State. The money will be used under a cooperative agreement and work plan between ADC and the Nebraska Department of Agriculture.

The Oklahoma Department of Agriculture increased its cooperative funding by $\$ 153,556$; this allocation is being used to fund several animal damage control specialist positions.
Texas increased its cooperative funding by a $\$ 200,000$ allotment that was used to fund four additional beaver control specialist positions in east Texas to respond to increasing requests for local assistance. The city of San Antonio also provided $\$ 20,000$ to $A D C$ for rabies suppression efforts in and around that city.

The Mississippi Department of Wildlife, Fisheries, and Parks provided $\$ 164,000$ in funding, and the Mississippi Department of Transportation provided $\$ 100,000$ to expand beaver control activities throughout the State.

In South Carolina, ADC, the State's Department of Transportation, and various counties initiated a cooperative program to reduce damage to roadbeds and bridges caused by beavers along State roads in an eight-county area. Adjacent landowners also benefit when beaver impoundments are drained from forest and agricultural lands. Interest in ADC expanding its beaver damagemanagement services in South Carolina is growing rapidly as private landowners and local governments from other regions of the State become aware of the economic benefits already being derived from the program.

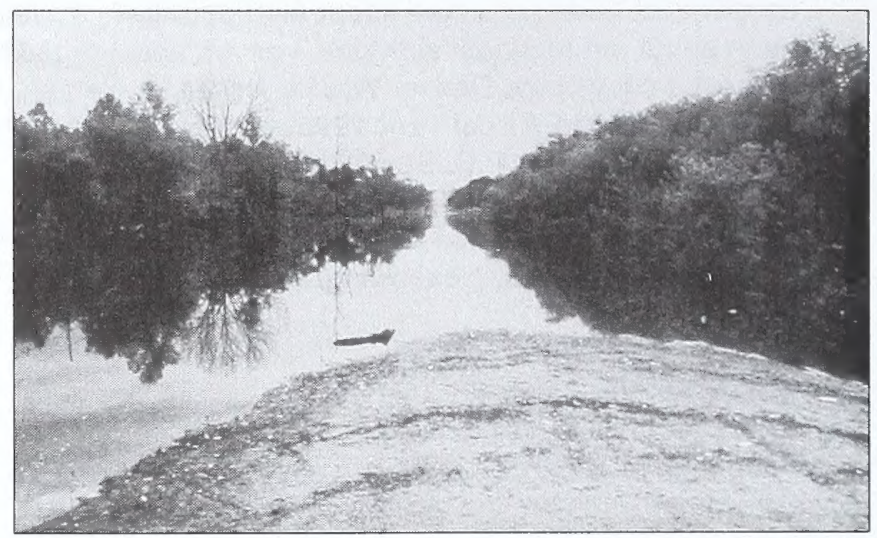

In North Carolina, the State's Wildlife Resources Commission and several counties increased cooperative funding by $\$ 278,372$ to expand the pilot beaver control program to 27 counties in response to increasing requests for assistance.

ADC was a sponsor of the second annual conference of The Wildlife Society held September 12-17, 1995, in Portland, OR. More than 2,000 wildlife biologists from around the world gathered for presentations on diverse topics of concern to natural resource managers. Several ADC employees made presentations on bird-aircraft protection, immunocontraception in wildlife management, chemistry in wildlife research, international trap standards, coyote-sheep 


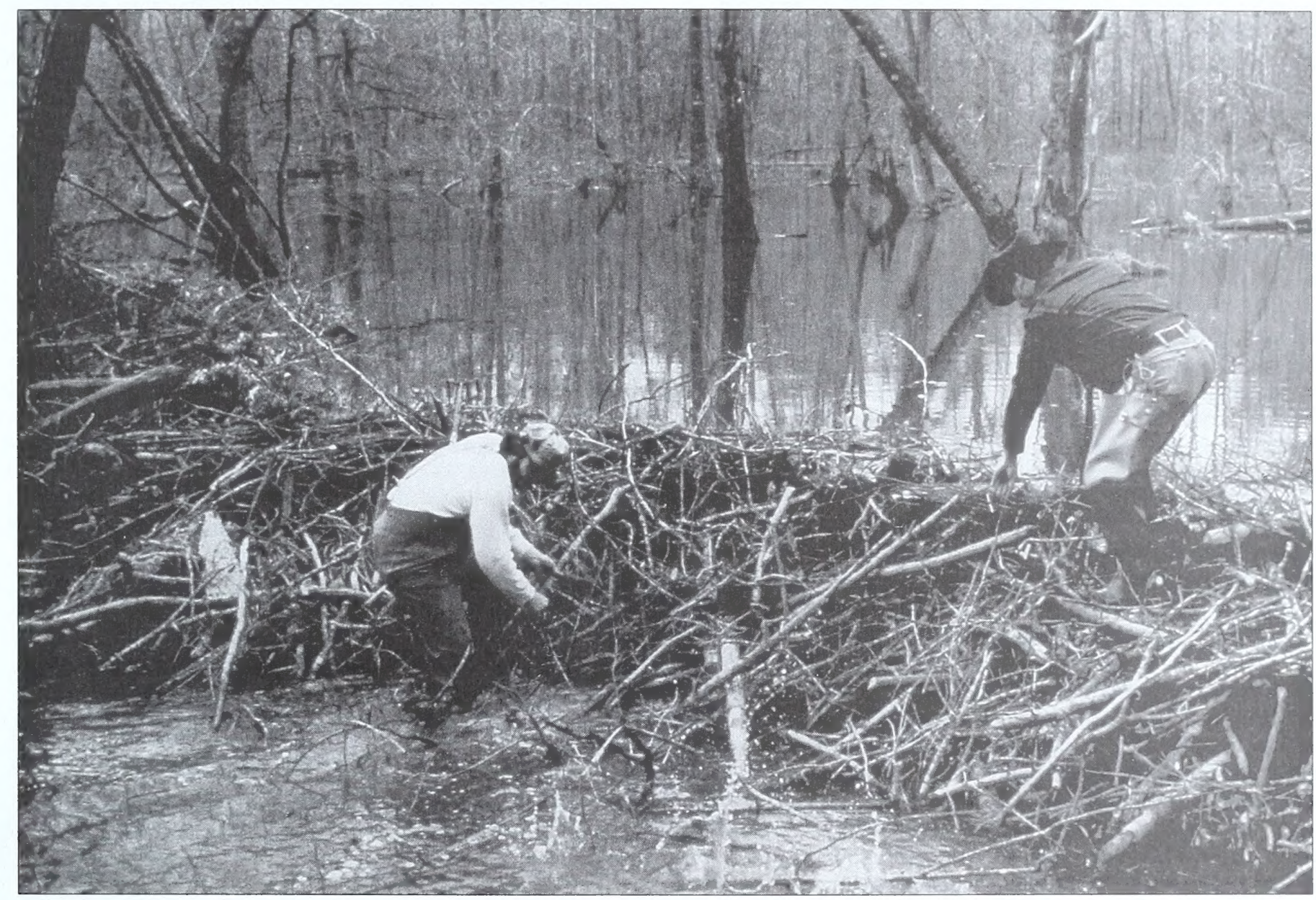

interactions, and crop damage by rats. An agency booth was also hosted by personnel from the Oregon and Washington State ADC offices.

We provided cooperative toll-free telephone services to the public in Maryland, Wisconsin, and Vermont. Phone bank personnel handled more than 22,500 wildlife damage management calls, including 18,500 relating to nuisance wildlife in Maryland and Wisconsin and 4,000 calls about rabies in Vermont. Cooperators in this service include the Maryland Department of Natural Resources, Wisconsin Department of Natural Resources, and the Vermont Departments of Fish and Wildlife, Health, and Agriculture.

\section{Workforce Planning Initiative}

During 1995, ADC offered two developmental opportunities designed to increase the workforce's leadership skills and the program's ability to fill future leadership vacancies.
The first developmental opportunity, a course entitled ADC Critical Skills Development for Nonsupervisory Personnel, was designed to build critical leadership skills in nonsupervisory personnel. To enable employees at all levels to prepare themselves to perform (formal or informal) leadership roles, the ADC Workforce Planning Team identified 12 leadership skills critical to the success of everyone in our workforce. These skills include vision/ change management, customer orientation, conflict management, teamwork and team building, concern for improvement, influencing and negotiating, leadership, interpersonal skills, creative thinking, problem solving, oral communication, and external awareness. In addition, limited matching funds were provided to help employees pay for a training course or developmental assignment to enhance their skill level in 1 or more of the 12 critical leadership skills. 
The second developmental opportunity, the ADC Leadership Excellence Program, is aimed at increasing the size of future candidate pools for select management positions. This comprehensive 18-month program includes leadership skills assessment, group coursework and individually tailored curricula, developmental assignments, leadership interviews, team projects, interaction with the ADC Management Team, and formal mentors. Ten individuals targeting Management Team, State Director, and Research Leader positions participated in the first session of this program, which was held in September.

Also during the year, the ADC Individual Development Planning Guide was distributed to provide employees with a tool to plan for their development for current and future positions. Included in the guide were position overviews of all ADC supervisory positions and the Management Competency Framework, which identifies skills needed at all levels of the organization.

\section{Brown Tree Snake (BTS) Control Program}

During FY 1995, the Department of Defense (DoD) allocated $\$ 1$ million to help fund the BTS program at nine military locations in Guam and Hawaii.

The discovery of a live BTS at Schofield Barracks on Oahu in the State of Hawaii in late December 1994 generated renewed concern within and beyond Hawaii. The snake was captured in a warehouse and apparently arrived on the island 9 days before in equipment returned to Hawaii from Guam. This was the first BTS at the Schofield Barracks, but six others have been documented at the shared facility of the Honolulu International Airport/Hickman Air Force Base since 1990 .

The control program includes the use of traps, glue boards, fencing, electrical barriers, detection dogs, habitat modification, and prey-base removal. Additionally, DoD funded research conducted by scientists at the Denver Wildlife Research Center (DWRC) to develop toxicants and fumigants for BTS control. Several toxicants and fumigants proved to be effective as potential control methods.

\section{Public Information}

ADC continued its "Living With Wildlife" public information campaign in 1995. Teachers throughout the United States received wildlife coloring and educational posters, "Both Sides of the Coin" activity sheets, factsheets, brochures, pens, pencils, rulers, and lesson plans. Additionally, articles about the availability of ADC educational materials were placed in Project WILD newsletters.

In October 1994, ADC's public affairs specialist attended an $\mathrm{Ag}$ in the Classroom conference in California and conducted five focus groups with teachers in an effort to develop lesson plans about conflicts between humans and wildife.
Throughout the year, items about wildlife management were placed nationwide in a variety of media markets, including the Kansas City Star, the Chicago Tribune, The Washington Post, the Wall Street Journal, Smithsonian magazine, Reader's Digest, CNN, ABC's 20120, the Los Angeles Times, National Public Radio, and several local newspapers and television stations.

ADC personnel set up exhibits at State fairs, agricultural shows, conferences, and community celebrations. Public affairs materials were distributed at the Minorities in Agriculture and Natural Resources conference as well as the annual Oshkosh Experimental Air Show. ADC also completed a national "Living With Wildlife" traveling exhibit, which was displayed at the Southeastern Wildlife Conference, the American Society of Landscape Architects Annual Meeting and Expo, and several other wildlife-related events.

Several informational materials were developed in 1995, including the Animal Damage Control 1994 Highlights Report and two new brochures, Animal Damage Control: Mission and Strategy, and Animal Damage Control Customer Service. New factsheets include "National Wildlife Research Center," "Denver Wildlife Research Center," "Living With Wildlife," "Careers in Animal Damage Control," "ADC Assistance With Waterfowl," and "ADC Assistance at Airports."

The University of Nebraska Cooperative Extension Service, the Great Plains Agricultural Council, and ADC edited and published a new, expanded version of the Prevention and Control of Wildlife Damage Handbook. This version contains 65 chapters and is intended for nationwide use. The handbook is also available on CD-ROM.

DWRC hosted a symposium on repellants in wildlife management in Denver, CO, August 8-10, 1995. The symposium brought together leading experts, resource managers, and others interested in repellants and their use in wildlife management to exchange ideas, discuss research findings, management approaches, and future research plans. Over 100 participants attended the symposium representing the United States and 7 other countries. The proceedings of this symposium will be published cooperatively by Colorado State University in 1996.

\section{DWRC Activities}

In December 1994, Richard Bruggers was selected as the Assistant Director for the Denver Wildlife Research Center. Dr. Bruggers was previously chief of DWRC's international programs section.

The Food and Drug Administration recently granted an Investigational New Animal Drug application to ADC to use propiopromazine hydrochloride in Tranquilizer Trap Devices 


\section{Protection of Agricultural Resources}

attached to traps and snares set to capture coyotes and wolves. The tranquilizer will immobilize the captured animals for up to 24 hours, thereby helping reduce stress and trap-related injuries.

The first building of a state-of-the-art research facility for the National Wildlife Research Center (NWRC) was completed in January 1995 on the foothills campus of Colorado State University in Ft. Collins. The new facilities, being completed as part of a master plan for NWRC, will allow for the future relocation of all DWRC headquarters activities to $\mathrm{Ft}$. Collins. Initial research will emphasize developing attractants and repellants, a research area that promises to produce new, effective, and socially acceptable wildlife management methods. Planning and design activities are under way to develop additional facilities on the remainder of the 43-acre site. These plans include offices, laboratories, a conference and technology transfer center, maintenance shops, and outdoor animal holding and research facilities for a variety of mammal and bird species.
Birds and mammals of many species cause damage to food crops and livestock worth several hundred million dollars annually. Blackbirds and starlings regularly consume grain crops in all stages of growth, from sprouting seeds to mature crops. Affected crops include wheat, corn, rice, sorghum, and sunflowers. Ducks and geese trample, eat, and foul swathed grain and seeds. Fish-eating birds cause serious losses to catfish and other fish grown at aquaculture facilities. Mammals, such as deer, prairie dogs, gophers, and raccoons, also cause damage to a wide variety of foods crops. Certain predators cause significant damage to the livestock industry by killing or injuring sheep, goats, cattle, poultry, and other kinds of livestock.

Here are some specific examples of ADC's accomplishments in protecting U.S. agriculture in 1995:

- ADC responded to more than 1,400 black bear complaints in Wisconsin during the year. Over half of these complaints involved bears damaging agricultural resources. As a result of the requests for assistance, ADC trapped and relocated 607 problem bears.

- A sheep producer in southwestern Montana lost 30 ewes to coyotes in 2 nights during January 1995. At the time of the attacks, the sheepherder observed two coyotes decoy the livestock guarding dogs away from the sheep and over a hill. Six other coyotes then attacked the sheep. ADC specialists removed several coyotes from the area with aerial hunting and ground control methods before the losses stopped.

- After coyotes killed an emu valued at $\$ 15,000$, a Madison County, TX, resident contacted ADC for assistance. Although the bird was penned along with others, coyotes managed to enter the pen and make the kill. An ADC specialist surveyed the situation and used traps and M-44's at the site to remove four coyotes to prevent further losses.

- Many Wisconsin corn farmers experienced extensive crop damage from raccoons during the 1995 growing season. Although raccoon damage is not new to corn producers, an unusually high number of Wisconsin fields were affected during the year. ADC responded by recommending integrated damage management utilizing temporary electric fencing, scare devices, and trapping.

- In January 1995, sandhill cranes caused $\$ 4,000$ in damage when they grazed on a winter wheat pasture in Kearney County, KS. ADC specialists provided the farmer with technical information on harassment methods and suggested the use of Mylar ${ }^{\mathrm{TM}}$ flags and propane cannons to scare the birds away from the area. 


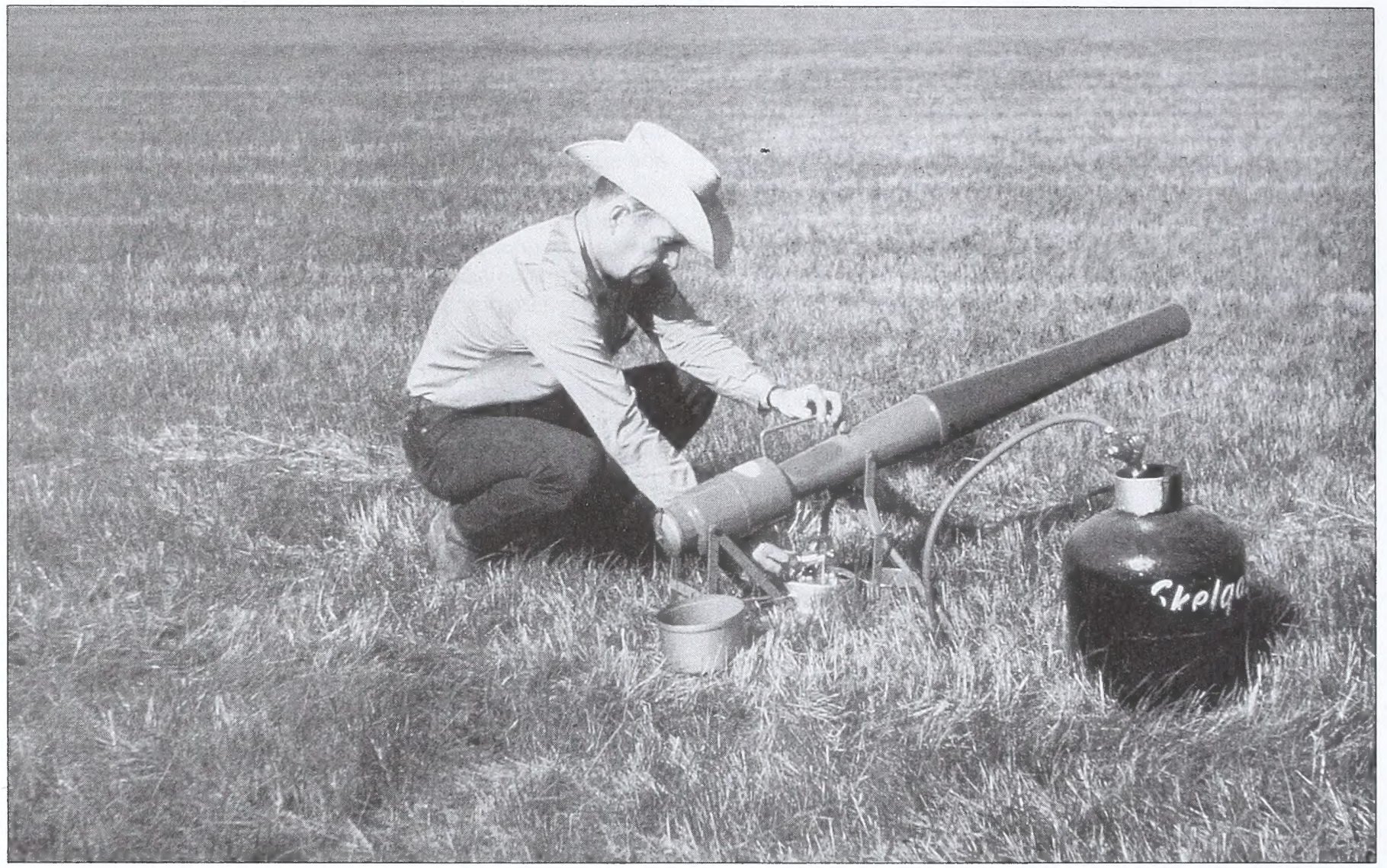

- A sheep producer in Idaho contacted ADC after losing 40 lambs to coyotes during the spring. Despite having a herder and three guarding dogs, the coyotes still killed the lambs. ADC specialists used a combination of control methods including traps, calling and shooting, and aerial hunting and removed six coyotes from the area to stop the losses.

- A rancher from Mendocino, CA, requested ADC assistance after reporting that a mountain lion had killed all of his livestock. The ADC specialists responding to the request confirmed that a lion had killed 11 goats and 2 llamas. The specialist captured a 150-pound male lion at the site, and no further predation has been reported.

- A commercial baitfish producer in Paragould, AR, estimated that lesser scaups caused approximately $\$ 500,000$ in losses to his aquaculture business the previous winter. This waterfowl species had never been present in such large numbers or caused extensive losses in the past. ADC prepared a damage management plan emphasizing harassment to be implemented during the winter months before the birds become habituated to feeding on commercial fish stocks.
- Blackbirds caused more than $\$ 50,000$ in damage to rice crops in Matagorda and Brazoria counties in Texas in early 1995. Both locations that received damage were adjacent to large roosting and staging areas used by the birds. ADC specialists, in cooperation with the Texas Agricultural Experiment Station in Beaumont, used the avian toxicant DRC -1339 to remove many of the blackbirds and reduce the incidence of further damage in the area.

- An ADC specialist in Solano County, CA, received a request for assistance from a local resident to help with a problem caused by beavers. The rodents had cut down nine mature pear trees valued at over $\$ 20,000$. The specialist removed four beavers from the area, and no further damage to the fruit trees has occurred.

- $A D C$ received numerous complaints from farmers in Arkansas reporting blackbird damage to their ripening rice crops. ADC personnel spent considerable time helping the farmers disperse the birds by establishing a bird scaring program using recorded blackbird distress calls, propane cannons, and various pyrotechnic devices. These methods were successful in scaring the birds away from the crops. 


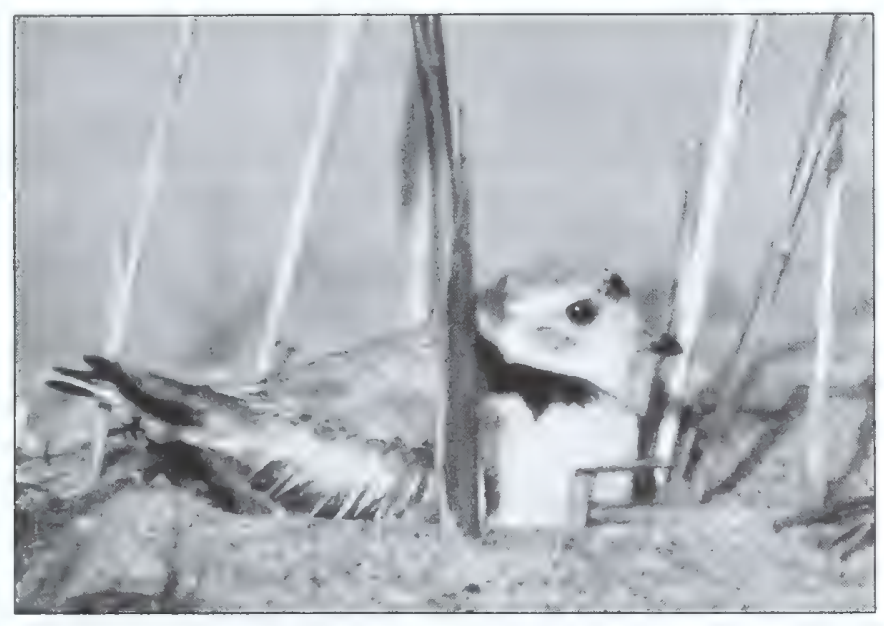

Specific Endangered Species Protection Efforts During 1995, the U.S. Department of the Interior's U.S. Fish and Wildlife Service (FWS) and several State wildlife agencies asked $A D C$ biologists to help protect threatened or endangered species. Those requests involved control activities to protect endangered warblers in Michigan, piping plovers in Nebraska, three species of salmon in Washington, Aleutian Canada geese in Alaska, and several endangered plants in Hawaii.

ADC was contacted by the Maine Audubon Society in January for assistance in protecting a nesting colony of endangered piping plovers from red fox predation during the upcoming nesting season. ADC provided electric fencing materials to personnel from the society so that they could construct a predator-proof fence to exclude the foxes. As a result of this effort, the nesting success for the piping plovers has increased significantly.

Biologists at DWRC captured 400 brown-headed cowbirds in early April to be used in the cooperative recovery effort for the endangered Kirtland's warbler in Michigan. The cowbirds are used as decoys to trap other cowbirds in the areas of jack pine forest where warblers nest, thereby reducing the incidence of nest parasitism during May and June. This was the 15th consecutive year that DWRC biologists from the Ohio Field Station have provided the FWS with cowbirds for this project.

In Washington State, ADC and the Chelan County Public Utility District entered into a cooperative agreement to reduce predation on salmon smolt caused by northern squawfish. Squawfish feed heavily on salmon smolts, and at least three species of salmon are listed as endangered in the Snake River and Columbia River. During the 14-week squawfish control program, more than 17,000 fish were removed. Cooperative funding in the amount of $\$ 106,483$ was provided to ADC by the District to conduct this control project.

ADC obtained a label from the Environmental Protection Agency during 1995 specifically to use the M-44 device to control arctic foxes in the Aleutian Islands in Alaska for the protection of threatened and endangered bird species. ADC conducted a joint training session with the Alaska

Department of Environmental Conservation in May to certify FWS employees for M-44 use. ADC will maintain strict monitoring of all M-44 use in Alaska via weekly reporting from FWS.

The Nevada Division of Wildlife and the Arizona Game and Fish Department requested $A D C$ assistance in a mountain lion survey. Nevada officials speculate that an endangered subspecies of lion, the Yuma puma, may be residing in southern Nevada. ADC captured four lions and collected blood samples for DNA analysis.

The U.S. Army garrison in Hawaii signed a cooperative agreement with $A D C$ during the summer to conduct feral goat and pig control operations in forest reserves and military reservations that they manage on the island of Oahu. These forests and mountains provide habitat for numerous species of endangered plants that are at risk from the goats and pigs. On the island of Kauai, ADC expanded its control program to include the Huleia National Wildlife Refuge near Lihue. In this area, feral cats and dogs that prey on endangered waterbirds are being removed.

In September 1995, a pack of six wolves killed at least three 500-pound calves about 40 miles southwest of Helena, MT. ADC's wolf management specialist confirmed the loss, and as directed by the FWS, trapped five of wolves, which are listed as an endangered species. The wolves were then relocated to another area where they were less likely to cause damage. No further predation on calves has occurred since the wolves were caught.

ADC assisted research biologists from Louisiana State University in capturing two nuisance Louisiana black bears on Avery Island, which is located in lower Iberia Parish. The bears, listed as threatened under the Endangered Species Act, caused school officials to become concerned about safety when the animals began frequenting the island's elementary schoolyard in search of food. The bears were immobilized and translocated 70 miles north to the Atchafalaya River National Wildlife Refuge to resolve the problem. 


\section{Protection of Property}

Other Natural Resources Protected

During 1995, ADC completed a project in cooperation with the Arizona Game and Fish Department (AGFD) to protect pronghorn antelope fawns in the northeastern portion of the State. AGFD biologists targeted critical areas where existing coyote populations were detrimental to pronghorn fawn survival, and under the direction of AGFD and ADC biologists, coyotes were removed from three game units by aerial hunting. In past years, these efforts have resulted in a significant increase in fawn survival.

In Idaho, ADC cooperated with the Idaho Department of Fish and Game in a project to remove predators from selected study areas as part of a 5-year study to explore causes of declining pheasant populations. Feral cats, striped skunks, and red fox were designated as target species.

ADC personnel recently completed the first stage of a coyote control effort on the National Bison Range Wildlife Refuge in northwestern Montana to increase antelope and bighorn sheep survival. During the past several years, fawn survival has been as low as 1 percent with the resident population of only 60 does. ADC personnel removed 11 coyotes from the refuge and 5 others from adjoining private land.

The Fish and Wildlife Service requested assistance from ADC to help control prairie dogs at the Ft. Niobrara National Wildlife Refuge in Nebraska. Prairie dogs on the refuge had increased to the point where they were competing with the captive bison herd. ADC used the rodenticide zinc phosphide to the prairie dog population in the area, and provided Fish and Wildlife Service officials with information so they could develop a management plan that would allow both prairie dogs and bison to exist in a reasonable balance.

ADC personnel worked cooperatively with officials from the Tennessee Wildlife Resources Agency on a project to reduce damage to a valuable bottomland hardwood forest caused by beaver-induced flooding on the Shelby Forest Wildlife Management Area. Losses included habitat for many species of migratory birds and forest wildlife as well as economic damage to timber resources. The primary emphasis of the project focused on removing the beaver dams to eliminate the flooding, followed by reducing the beaver population to acceptable levels for the area.

Near Wilcox, $A Z$, an adult female ostrich valued at $\$ 18,000$ was confirmed by ADC specialists to have been killed by coyotes. The bird had over a dozen eggs inside her which would have been worth $\$ 1,000$ each had they been laid. ADC specialists removed two coyotes from the ranch and provided the rancher with advice on how to maintain fences to deter other predators.
ADC was requested by the National Aeronautics and Space Administration (NASA) to help find a way to prevent woodpeckers from damaging space shuttle vehicles at the Kennedy Space Center in Florida. Damage to the shuttle by woodpeckers caused NASA to delay a scheduled flight for several weeks until repairs could be made to the spacecraft. ADC evaluated damage control strategies being attempted by NASA and participated in a meeting to identify viable alternatives. As a result of the meeting, a management plan for controlling woodpecker damage at the Space Center was developed by ADC and adopted by NASA.

The Young Men's Christian Association in Hoquiam, WA, contacted $A D C$ for help in dealing with a pigeon problem at the facility. Over time, a buildup of feces and nesting material from the birds resulted in deterioration of the eaves of the 5-story building. In addition, pigeons had gained access to the building's duct system and were nesting there. Repairs to the building cost $\$ 180,000$. ADC provided information on live-trapping methods and on ways to exclude the birds from the building to prevent future problems.

Officials of the Burlington-Northern Railroad requested assistance from $A D C$ to deal with a beaver problem in Grayson County, TX, in January. A colony of the rodents had damaged a drainage structure adjacent to a section of railroad track. The increased water level flooded the track bed causing settling that required the railroad to lower train speeds in that area from about $50 \mathrm{mi} / \mathrm{h}$ to about 10 . Damage was estimated at about $\$ 8,000$. ADC specialists removed 11 beavers from the area to prevent further damage and reduce the safety threat.

A white-tailed deer disrupted production in a paper mill in Eau Claire, WI, when it entered the mill and became disoriented. ADC personnel responded to the request for assistance by quickly immobilizing the animal with a tranquilizer dart. The deer was later released unharmed on a State wildlife management area. 
ADC has been active in its role to protect human health and safety through the control of animal-borne diseases and wildlife hazards to aircraft. We have removed a number of dangerous animals, such as black bears and mountain lions, from public areas. ADC biologists assist State and local health departments in controlling animals in areas where wildlife disease outbreaks threaten public health. We also conduct programs at airports, where collisions between wildlife and aircraft pose a serious safety hazard to passengers.

\section{Public Safety}

On December 10, 1994, a woman hiking in Cuyamaca State Park about 25 miles east of San Diego, CA, was killed by a mountain lion. Park officials immediately requested the California Fish and Game Department and ADC to assist in locating the lion. ADC recommended that a deer carcass be placed at the location of the kill to hold the suspected lion in the area until the lion could be captured. The carcass was fitted with a transmitter which would activate if the carcass was moved. About 30 minutes after the carcass was placed, the transmitter emitted a signal, indicating that the lion had returned. ADC personnel used trailing hounds and treed a mature male lion near the site. The lion was killed, and subsequent examination of tooth spacing and human DNA confirmed that the animal was responsible for the attack on the woman.
In February 1995, ADC, the State of Texas, and Rhone Merieux, Inc., worked together to distribute 850,000 oral vaccine/bait units aerially across a $14,400-\mathrm{mi}^{2}$ target area in south Texas. ADC personnel later collected approximately 500 coyotes throughout the vaccine/bait drop area to provide to labs in Texas, Georgia, and Ontario, Canada, for testing to determine what percentage of the coyotes had consumed the baits and to test blood titers from the coyotes that ingested the vaccines. Initial results indicated that 42 percent of the coyotes that consumed at least one bait showed a response to the vaccine. Further bait drops are scheduled for early 1996 and will be expanded to include areas in west-central Texas where there is presently a rabies outbreak in foxes.

ADC personnel met with environmental engineers at the New York City Supply Reservoir during 1995 regarding contamination of the city's water supply by gulls. Fecal deposits from gulls using the system's final-stage treatment reservoir resulted in unacceptable levels of coliform bacteria. The reservoir provides water for the entire New York City area. ADC assisted by developing a harassment plan to augment wire grid structures recommended to deter incoming gulls.

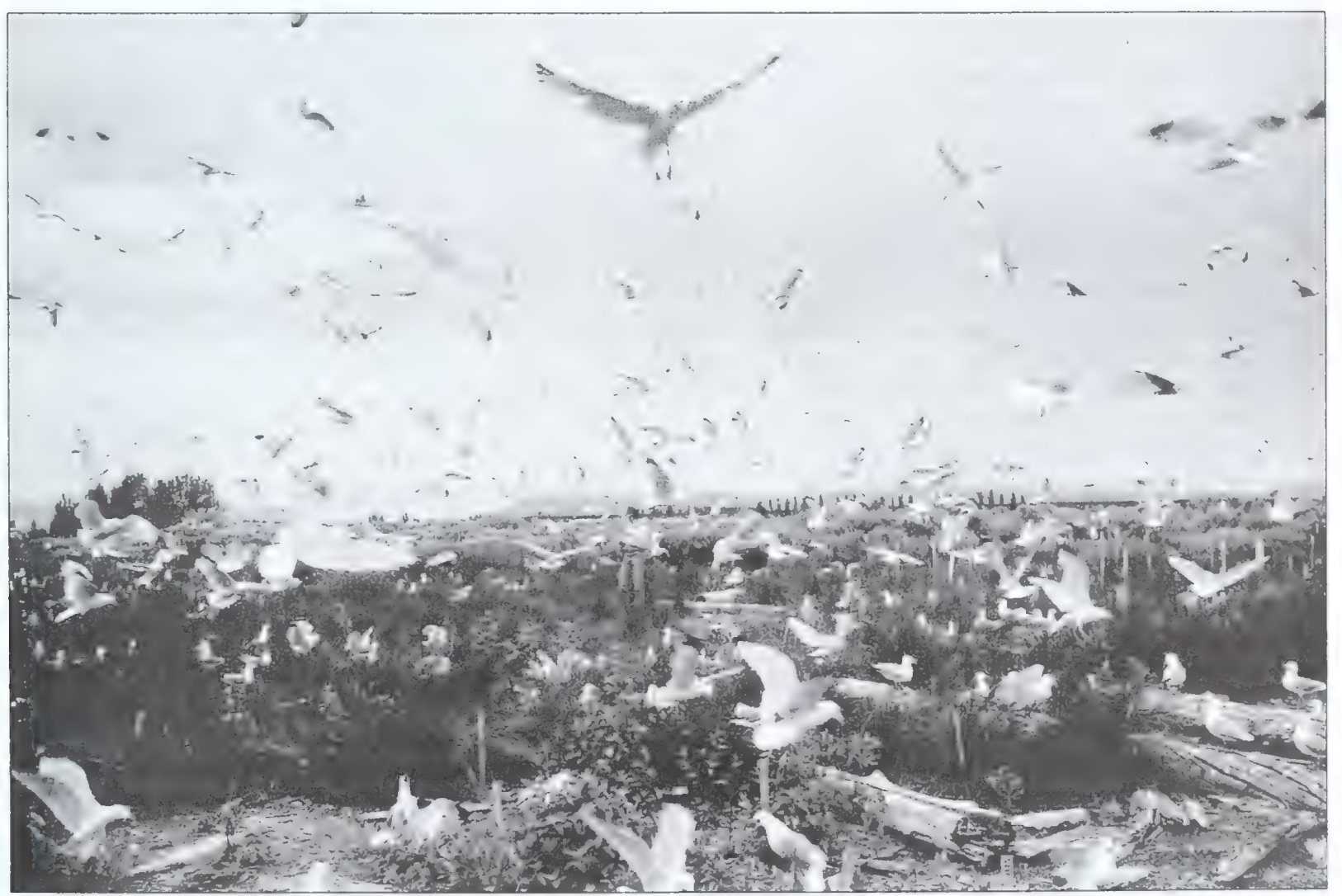


American coots caused an unusual highway safety hazard on Interstate 10 near Mobile, AL, during FY 1995.

Numerous near collisions occurred when vehicles swerved to avoid coots attempting to land on the $1-10$ bridge over Mobile Bay during inclement weather. More than 200 coots were killed by automobiles over a 2-week period. Among the recommendations provided to the Alabama Department of Transportation included the use a variety of scare tactics to keep the birds away from the area during bad weather.

In March, a mountain lion attacked a visitor in a national forest north of Los Angeles, CA. The man was riding a mountain bike when he saw the lion charging him. The lion attacked him, biting and scratching him on his head and arms. The man grabbed a large rock and hit the animal several times on its head, causing the lion to flee. The California Department of Fish and Game requested ADC assistance to capture the lion, and the ADC specialist who responded caught it a few days later.

The ADC Rabies Information Service, established in Vermont to address public concerns about the northward spread of the mid-Atlantic strain of rabies, completed its third year of operation. During FY 1995, the toll-free telephone service logged in 4,096 calls, representing a 77 percent increase over 1994.

Four people were bitten by rattlesnakes during the summer of 1995 in the Amarillo, TX, panhandle area. One was a near-fatal incident involving a 71-year-old man. News coverage of the problem prompted an increase in calls to the ADC office. Personnel from ADC and the Texas Parks and Wildlife Department provided interviews to a local television station, including information on damage prevention, rodent control, and the rattlesnake biology. The news segment aired several times and helped allay citizen concerns.

Safety hazards and health concerns were caused by several hundred black and turkey vultures roosting on a radio transmission tower at a private aerospace company in Seville, FL. Many of the company's employees refused to work because of the heavy feces deposits on the tower and associated equipment. Sensitive military transmission equipment on the tower is critical for safe operations at the nearby National Aerospace Civil Firing Detachment-Aster bombing range. ADC assisted company officials in developing an action plan that included monofilament lines placed across prime perching areas on the tower to exclude the birds and the use of noise-making devices to scare the birds away from the area.

\section{Airports}

Birds and mammals around airports present a threat to public safety when they collide or get sucked into engines. As a result, U.S. aviation regulations (14 Code of Federal Regulations, Part 139) require airports experiencing wildlife-aircraft conflicts to develop and implement wildlife management plans.

Because most airport employees lack the technical expertise to identify the causes of wildlife hazards, the Federal Aviation Administration and ADC entered into a cooperative agreement in 1989 to resolve wildlife hazards at airports. At the request of either the Administration or airport management, ADC specialists provide technical and/or operational assistance to reduce or control wildlife hazards to aircraft. During 1995, ADC personnel provided such assistance to approximately 350 airports throughout the United States. ADC also conducts an agency-developed training program for airport managers and other airport employees regarding bird identification and available control methods. (ADC provides the same service to the U.S. Air Force as well.)

The following accounts represent a variety of problems reported during 1995 and describe the action taken by ADC to resolve wildlife-aircraft hazards.

- ADC continued to provide assistance to John F. Kennedy (JFK) International Airport in New York City to reduce bird strikes to aircraft. As a result of this program, where laughing gulls crossing JFK airspace are removed by shooting, bird strikes have been reduced by approximately 75 percent. ADC also conducted training sessions on nonlethal bird control techniques to JFK personnel and assisted in reviewing landscaping plans to ensure that bird attractants are excluded.

- ADC personnel actively participated in the fifth Bird Strike Committee USA Conference held at the Dallas-Ft. Worth International Airport in August. The annual conference facilitates information transfer, coordinates the development of new technologies, and provides training on bird hazards to aviation. ADC biologists presented several technical papers, participated on a discussion panel, and conducted hazard control training for approximately 120 attendees.

- Serious safety hazards posed by Canada geese at the Marshall Municipal Airport in Missouri were reported to ADC in January 1995 after a twin-engine aircraft struck a goose and the impact damaged the aircraft's wing. A site visit by ADC officials revealed approximately 300 Canada geese feeding in cropland adjacent to the runways. ADC recommended pyrotechnics to frighten the geese, reinforced by hunting. City officials implemented a harassment program and removed geese from the airport and adjacent areas during the State goose hunting season. No further problems have occurred. 


\section{Environmental Compliance}

- Officials at the Hector International Airport in Fargo, ND, contacted $A D C$ for help with removing white-tailed deer from a secured area on airport property. The number of incidents of deer on the runways at the airport had been steadily increasing, and there was fear of a deer-aircraft collision. ADC specialists removed seven deer and airport officials then donated the deer to "Hunters for the Hungry," an organization that provides meat to food charities.

- Bird-aircraft strikes at Dulles International and National airports in the Washington, DC, area involving Canada geese prompted airport officials to seek ADC assistance after an intensive harassment program failed to reduce the hazard. With assistance from the Virginia Department of Agriculture, ADC captured 318 resident geese from Dulles and National during the birds' flightless summer molt period. A number of the geese were relocated to the Tidewater region of Virginia, and the remainder were donated to charitable organizations for use as food.
In March 1995, the Acting APHIS Administrator signed the record of decision for ADC's program's final environmental impact statement (EIS). In the decision, it was determined that aspects of most of the alternatives analyzed in the final EIS are currently being used in specific situations across the United States. Because the EIS is programmatic in nature and national in scope, a single alternative as the sole, allencompassing focus of the ADC program may not adequately cover all wildlife damage problems and situations. Therefore, the decision was made to send forward to regional and local ADC decisionmakers the viable alternatives discussed in the final EIS for consideration as management approaches, when appropriate, practical, and reasonable, in preparation of local and site-specific documents and actions. This decision will provide a complete range of wildlife damage control strategies available as part of an overall integrated management approach.

During the year, memoranda of understanding with the U.S. Department of the Interior's Bureau of Land Management and USDA's Forest Service were completed acknowledging ADC's lead responsibility for NEPA compliance for predator management actions on Federal lands managed by those agencies.

ADC also completed and signed records of decision for activities on the Lincoln, Apache-Sitgreaves, Lewis and Clark, Challis, Big Horn, Sawtooth, and Wallowa-Whitman National Forests in the Western United States.

In May 1995, ADC hired three environmental coordinators stationed at the Albuquerque, NM, Portland, OR, and Billings, MT, State ADC offices. These individuals will be under the supervisory responsibility of the ADC environmental manager, who was transferred to the Western Regional Office in Lakewood, CO, a month earlier. Each new environmental coordinator will be responsible for six States in the Western Region. 


\section{Customer Service and Program Evaluation}

During 1995, we developed an ADC customer service brochure for the program. This brochure explains our purpose, our mission, the services we provide, and the standards that you can expect when you contact us. It also explains how to contact us if we don't meet your expectations. Published in April 1995, the brochure has been provided to all employees for distribution to customers, stakeholders, and others who have an interest in our program.

At ADC's request, APHIS' Policy and Program Development section began the second phase of an evaluation to determine customer satisfaction. To learn if customers were satisfied with technical assistance services provided by ADC, approximately 2,000 technical assistance customers will be randomly sampled in early FY 1996. Results will be analyzed and published in the 1996 highlights report. The technical assistance evaluation is the final phase of a project that began in 1993 to determine overall customer satisfaction with the program. 

